\title{
Use of the activity-based costing methodology (ABC) in the cost analysis of successional agroforestry systems
}

\author{
J. B. C. N. Araújo (1) A. N. Souza • M. S. Joaquim • L. M. Mattos • I. M. Lustosa Junior
}

Received: 20 June 2017 / Accepted: 9 February 2019

(C) Springer Nature B.V. 2019

\begin{abstract}
Facing increasingly competitive market demands, producers must act as managers of their property, knowing the strengths and bottlenecks in production systems. In this perspective, there is a methodology activity-based costing system (ABC), a cost management tool, used when there is a mix of products, to determine the unit costs of production. This work aimed to apply the activity-based costing system to activities in a successional agroforestry system, that produces nine products. The methodology was applied to the indirect costs of the system. When applying the methodology, it was found that maize and okra products presented negative contribution margins, showing that the respective production costs exceed the sale value of the product. The other products had positive contribution margins, with
\end{abstract}

J. B. C. N. Araújo $(\bowtie) \cdot$ A. N. Souza ·

I. M. Lustosa Junior

Departamento de Engenharia Florestal, Universidade de

Brasília, Campus Universitário Darcy Ribeiro,

Cx.P. 04357, Brasília CEP 70.910-900, DF, Brazil

e-mail: juliana.bcneves@gmail.com

M. S. Joaquim

Faculdade de Agronomia e Medicina Veterinária, Universidade de Brasília, Campus Universitário Darcy Ribeiro, Cx.P. 04357, Brasília CEP 70.910-900, DF, Brazil

L. M. Mattos

Embrapa Cerrados, Rodovia BR-020, km 18,

Planaltina, Brasília CEP 73.310-970, Brazil emphasis on yam and strawberry. The $\mathrm{ABC}$ system is efficient for management and administration of agroforestry enterprises.

Keywords Activity based costing · Costs . Agroforestry system

\section{Introduction}

Increasing the productivity of food production while minimizing dependence on fossil fuels, protecting biodiversity and increasing the quality of the environment are major challenges for today's society. Therefore, alternative production models with positive externalities and capable of providing multiple environmental services are defended (Souza et al. 2012). There is a national trend towards new productive and economic processes that reconcile economic development with poverty reduction and environmental conservation strategies (ICRAF 2011).

In this perspective, there are agroforestry practices where, according to the Association of Agroforestry Systems in Temperate Regions (AFTA), management practices and intensive use of the soil seek to optimize the benefits generated by the interaction between trees and/or shrubs with agricultural crops and/or animals (AFTA 2016), using special and temporal arrangement. In this scenario, successional agroforestry 
systems are interesting because they aim to simulate the ecological dynamics of natural forests.

Therefore, agroforestry systems increase the functionality of agriculture, supporting not only the process of food and productive sovereignty, but also the community economy and protection of biodiversity (Altieri and Nicholls 2011). Although ecological advantages are obtained by the use of agroforestry systems, this activity is still complex and presents uncertainties from an economic point of view, as well as other more traditional agricultural and forestry activities (Bentes Gama et al. 2005).

According to Bentes Gama (2003), gathering a set of agricultural and forestry activities to conduct planting and to manage the species that make up the system is why the agroforestry activity becomes complex. Since it combines several technical variables and has a great range of costs, the use of methodologies that investigate them is justified. Facing a globalized and competitive world, there is a need for the market to transform and overcome the impacts of technological innovations and consumer demand. The same reality exists in the rural environment, thus requiring the producer to have a rural managerial attitude, prioritizing the development and implementation of management techniques and consolidating information and property results (Sampaio et al. 2011).

In this way, an important aspect to be analyzed by the managers is the expense incurred in order to keep an activity in operation and guarantee production in order to meet market demands (Wernke 2005). Financial analysis can be significantly optimized using specific and detailed data provided by alternative methodologies. To that end, such data must be processed in a way that can provide important information for the decision-making process. In this perspective, accounting tools can be used to improve the analysis of costs and variables of interest (Carli and Canavari 2013).

Accounting makes use of costing systems to solve problems related to cost measurement and aims to improve the productive process, these systems are able to determine the unit cost of each product or service performed (Roschel et al. 2013). To meet this need, activity-based costing (ABC) is shown as a tool capable of improving the financial management of an enterprise, since it makes it possible to understand how the costs of an activity are related to the generation of revenue (Wernke 2005). It is able to provide primary information on variability of the production process as well as resource utilization (Anzai et al. 2017).

The ABC costing system was born due to the need for a clearer calculation of product costs and to show the consumption of direct and indirect resources. Thus, it helps in the process of price formation of the product, so that it is compatible with the market in which the product is inserted (Silvestre 2002). The correct use of the costing system is important, since the incorrect division of costs can cause uncertainties in the determination of profit for each product and thus jeopardize decision-making process (Cremonese et al. 2016).

The $\mathrm{ABC}$ is a cost management tool used in the decision-making process when there is a production of a mix of products (Cremonese et al. 2016). Direct and indirect costs are the consequence of the execution of activities, which consume resources when they are carried out. Therefore, ABC provides more accurate product costs than other accounting methodologies (Diehl and Souza 2008; Garrinson et al. 2013). In addition, $\mathrm{ABC}$ tracks the cause of costs and thus allocates costs to objects, while other costing methods do so via apportionment. The use of this methodology is recommended for enterprises that have a diversity of products (Diehl and Souza 2008).

By using the $\mathrm{ABC}$ costing system, therefore, it is possible to see how effectively the resources are being used and how all activities contribute to the final cost of each product. However, the level of detail required for the data may be a difficulty that justifies its nonuse, especially for family farmers and medium-sized producers (Suthummanon et al. 2011). Under this perspective, the objective of this work was to perform cost analysis of a successional agroforestry system applying the activity-based costing methodology (ABC).

\section{Materials and methods}

The agroforestry system under study is located in Brasília-Federal District, Brazil. And, for this study, data were collected from three plots and four wind breaks, totaling an area of 0.0264 ha (Fig. 1). The data used were collected daily from the producer, referring to the costs, inputs, productivities, revenues and time of accomplishment of the activities necessary to 
Fig. 1 Study area sketch representing the devices and wind breaks (Source: Brazilian Agricultural Research CorporationEmbrapa)

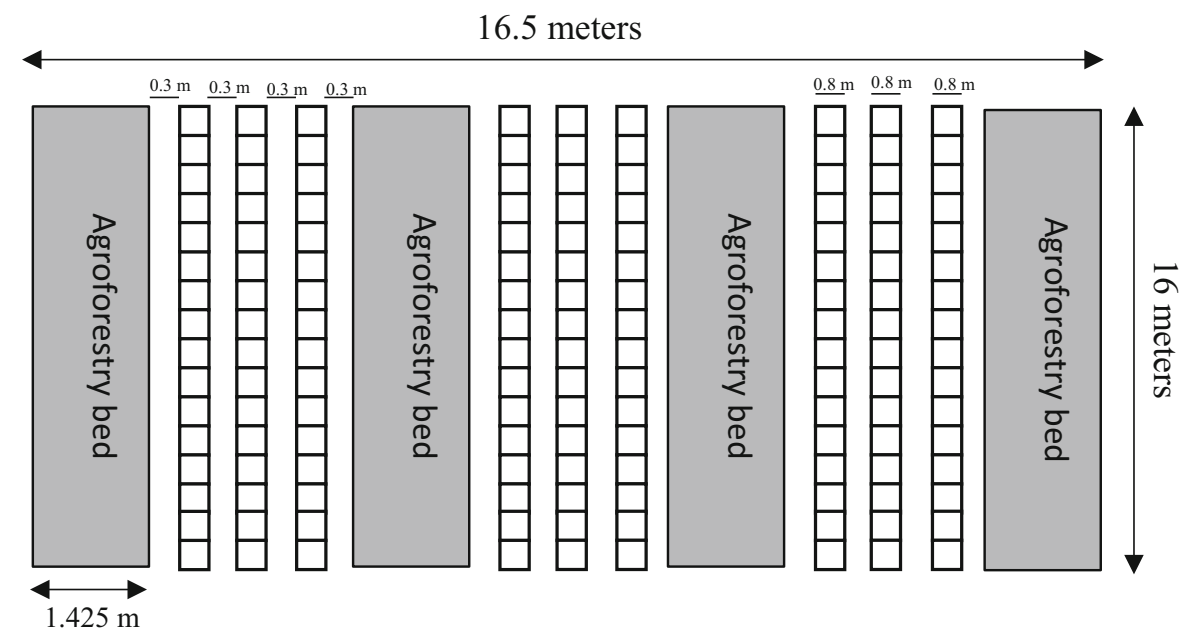

produce the products of the studied agroforestry system. It covers a period of 4 years, encompassing data from the general preparation, implantation, handling and harvesting of the products of the system.

Plots and wind breaks were composed of agricultural and forest species (Table 1) within a spatial and temporal arrangement. The species used were arugula, lettuce, broccoli, maize, yam, cherry tomato, strawberry, okra, banana, coffee and eucalyptus.

The methodology used in the study was based mainly on Martins (2010) and Padoveze and Takakura Junior (2013). The sets of tasks performed in the system, was identified as necessary to achieve the

Table 1 Species (scientific and common name) used in the analyzed agroforestry system, with the respective densities in the area

\begin{tabular}{|c|c|c|}
\hline \multicolumn{2}{|l|}{ Species } & \multirow{2}{*}{$\begin{array}{l}\text { Density } \\
\text { (Plants/total area) }\end{array}$} \\
\hline Scientific name & Common name & \\
\hline Eruca sativa & Arugula & 960 \\
\hline Lactuca sativa & Lettuce & 720 \\
\hline Brassica oleracea & Broccoli & 384 \\
\hline Zea mays & Maize & 96 \\
\hline Colocasia esculenta & Yam & 48 \\
\hline Solanum lycopersicum & Cherry tomato & 24 \\
\hline Fragaria vesca & Strawberry & 240 \\
\hline Abelmoscus esculentus & Okra & 24 \\
\hline Musa sp & Banana & 16 \\
\hline Coffea arabica & Coffee & 32 \\
\hline Eucalyptus grandis & Eucalyptus & 16 \\
\hline
\end{tabular}

productive process. First, it is necessary to list all the activities carried out, in order to effectively characterize their operation and performance.

For application of this methodology, the production costs of the crops were divided into direct and indirect costs. The ABC method was applied to indirect production costs. Direct costs were also processed to determine unit direct costs, total unit costs, and the marginal contribution of each product.

Next, the data were assigned directly to the activities performed by the producer, according to the time spent to perform the activity and the cost generated for realization. This procedure was used for all the activities of the system: general preparation, planting, maintenance and harvesting. The inputs used to carry out the activities and quantity produced by the crops were also annotated in the field records.

Subsequently, the activities were assigned costs and the sum of resources used periodically to perform the selected tasks was quantified. Thus, it was possible to identify and select the resource drivers (factors that determine the cost of a given activity, expenses that have a direct relation with the activities performed), as shown at the Fig. 2. And finally, the costs of the activities were attributed to the products, and the product was evaluated with the use of Eqs. (1), (2) and (3):

$C d=\frac{C a}{N t d}$

$C a p=C d x N d$ 
Fig. 2 Methodological framework using $\mathrm{ABC}$

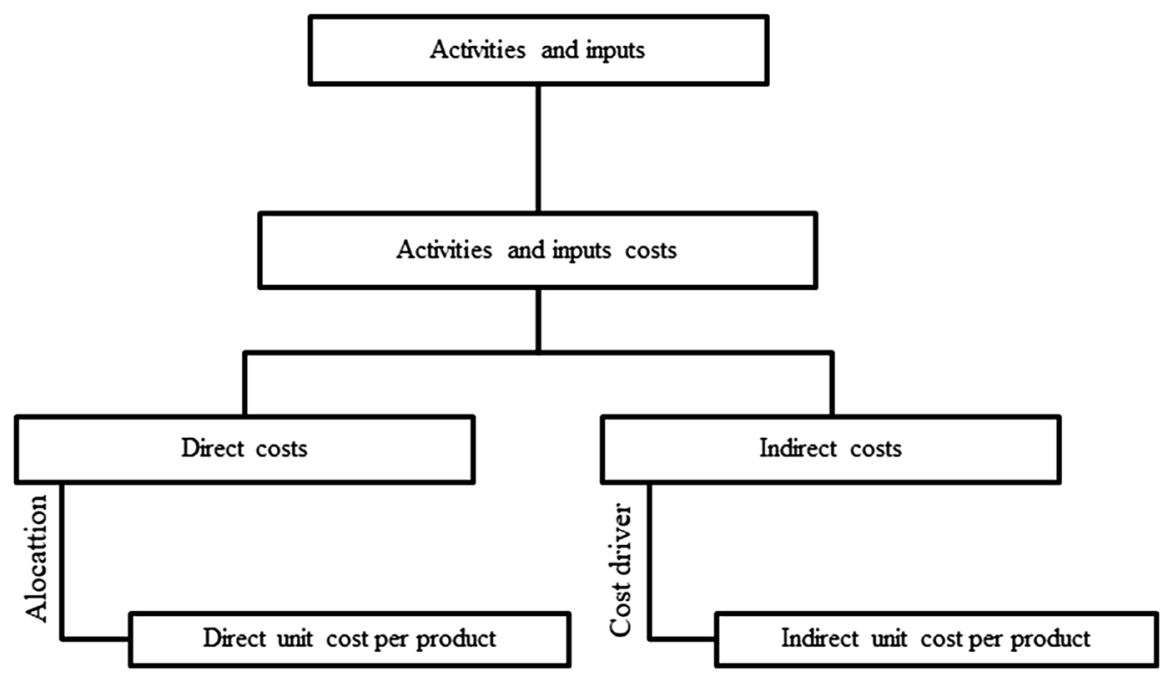

$$
\text { Caup }=\frac{C a p}{Q}
$$

where $\mathrm{Cd}$ is the unit cost of the driver; $\mathrm{Ca}$ is the cost of the activity; Ntd is the total number of drivers; Cap the cost of activity per product; $\mathrm{Nd}$ the number of drivers; Caup the cost of activity per unit of product; and $\mathrm{Q}$ is the quantity produced.

\section{Results and discussion}

The analyzed agroforestry system presents the following cost-generating activities: general preparation, planting, maintenance (bed and windbreak) and crop harvesting, as shown in Table 2. In addition, we also

Table 2 Total costs $(\mathrm{R} \$ / \mathrm{ha})$ related to the activities carried out in the analyzed agroforestry system

\begin{tabular}{lrl}
\hline Cost-generating activities & Total cost & $\%$ \\
\hline General preparation & $47,977.27$ & 14.25 \\
Bed fertilizing & 8363.64 & 2.48 \\
Bed planting & $44,000.00$ & 13.07 \\
Bed maintenance & $45,000.00$ & 13.37 \\
Maintenance of the agroforestry bed & 9547.35 & 2.84 \\
Crop harvest & $60,272.73$ & 17.90 \\
Inputs & $121,479.77$ & 36.09 \\
Total & $336,640.76$ & 100 \\
\hline
\end{tabular}

$1 \mathrm{US} \$=\mathrm{R} \$ 3.20$ in June, 2017 have the inputs responsible for supplying material to carry out the activities.

The inputs were the cost generators with the greatest influence on the total cost of the agroforestry system, with $36.09 \%$. Rezende et al. (2009), found that in the consortia of lettuce, cabbage, arugula and radish with pepper the values were, respectively: $49.6 \%, 63 \%, 57.2 \%$ and $65.2 \%$.

Based on the concepts of costs, where direct costs are those that have a clear and quantifiable relationship with the final product and indirect costs are not so easily quantifiable, costs have been divided into direct and indirect costs (Table 3). Subsequently, the proposed methodology was applied and the unit costs were determined.

Table 3 Definition of direct and indirect costs related to production in the analyzed agroforestry system

\begin{tabular}{lc}
\hline Cost-generating activities & Cost type \\
\hline General preparation & Indirect \\
Bed fertilizing & Direct (*) \\
Bed planting & Indirect \\
Bed maintenance & Direct \\
Maintenance of the agroforestry bed & Direct \\
Crop harvest & Indirect \\
Inputs & Direct (*) \\
\hline (*) Part of these activities are also included in general \\
preparations and, therefore, some of these costs were \\
considered indirect for the calculations
\end{tabular}


Table 4 Direct costs (R $\$ /$ ha) of the inputs used to produce the agroforestry products of the system

\begin{tabular}{|c|c|c|c|c|c|}
\hline Product & Quantity produced (kg/ha) & Inputs & Cost & Direct unit cost & Partial direct unit cost \\
\hline \multirow[t]{2}{*}{ Arugula } & \multirow[t]{2}{*}{$41,212.12$} & Chicken manure (kg) & 2727.27 & 0.07 & \multirow[t]{2}{*}{0.26} \\
\hline & & Seedling (un) & 8181.82 & 0.20 & \\
\hline Lettuce & $36,363.64$ & Seedling (un) & 6136.36 & 0.17 & 0.17 \\
\hline \multirow[t]{2}{*}{ Broccoli } & \multirow[t]{2}{*}{$23,333.33$} & Chicken manure (kg) & 681.82 & 0.03 & \multirow[t]{2}{*}{0.28} \\
\hline & & Seedling (un) & 5965.91 & 0.26 & \\
\hline \multirow[t]{2}{*}{ Maize } & \multirow[t]{2}{*}{4545.45} & Chicken manure (kg) & 2727.27 & 0.60 & \multirow[t]{2}{*}{0.78} \\
\hline & & Seedling (un) & 814.55 & 0.18 & \\
\hline Yam & $18,181.82$ & Seedling (un) & 1818.18 & 0.10 & 0.10 \\
\hline \multirow[t]{2}{*}{ Cherry tomato } & \multirow[t]{2}{*}{$18,181.82$} & Chicken manure (kg) & 2727.27 & 0.15 & \multirow[t]{2}{*}{0.33} \\
\hline & & Seedling (un) & 3272.73 & 0.18 & \\
\hline \multirow[t]{2}{*}{ Strawberry } & \multirow[t]{2}{*}{$36,363.64$} & Chicken manure (kg) & 779.17 & 0.02 & \multirow[t]{2}{*}{0.37} \\
\hline & & Seedling (un) & $12,727.27$ & 0.35 & \\
\hline Okra & 1818.18 & Seedling (un) & 426.14 & 0.23 & 0.23 \\
\hline Coffee & 751.52 & Seedling (un) & 1212.12 & 1.61 & 1.61 \\
\hline
\end{tabular}

$1 \mathrm{US} \$=\mathrm{R} \$ 3.20$ in June, 2017

Direct costs were attributed to the products, according to the respective quantities produced, based on the amount of resources consumed to carry out the activities, as shown in Tables 4 and 5 . Where it can be seen that the harvest-related activity represents $38.24 \%$ of the direct costs related to the activities of the system, followed by maintenance of plantation (28.55\%), planting (27.91\%) and fertilizing (5.3\%). Moraes (2013), in a study on agroforestry system costs, found that manual harvesting represented more than $57 \%$ of total costs. It is important to note that eucalyptus pruning operations will represent a significant increase in labor costs after 4 years (analysis 'period of this case study).

Thus, the direct costs used to produce the agroforestry products of the site are shown in Table 6. It can be seen that coffee and okra are the products that consume the greatest amount of direct resources for production, since they are products with lower productivities and, therefore, direct costs are less diluted in production. But it's necessary to considerate that coffee production still did not reach the apex of production after 4 years. The coffee begins its full production from 5 years of planting and its minimum exploitation can last 25 years.

The methodology was applied, therefore, to the indirect costs of the agroforestry system and, thus, determined the drivers of costs related to the products (Table 7). Subsequently it was possible, therefore, to attribute the costs to the activities and to carry out the costing of the agroforestry products (Tables 8 and 9), according to the proposed methodology.

The activity with higher costs was the use of the rotary brush cutter to prepare the area prior to planting of the beds, just as it did for the direct costs. It is therefore inferred that identifying the costs of the activities as well as the costly activities allows the producer to identify the main cost centers and provides subsidies for a possible performance evaluation or establishment of management plans capable of optimizing the use of resources (Pimenta et al. 2007).

In consortium systems, when compared to conventional systems of single crop or planting of a particular species, there is a reduction in the cost of production due to the smaller numbers of manual and mechanized activities, as well as smaller quantities of necessary inputs per product. The integrated plantation promotes cost reduction by agricultural species, since there is a full use of inputs. The activities carried out for a given culture influence the surrounding cultures. In addition, due to the ecological dynamics established in the intercropping systems, phytosanitary treatments are also minimized because there is an optimization of the soil cover (Rezende et al. 
Table 5 Direct unit costs $(\mathrm{R} \$ / \mathrm{ha})$ of the activities carried out to produce the agroforestry products of the system

\begin{tabular}{|c|c|c|c|c|c|}
\hline Product & Quantity produced (kg/ha) & Activity & Cost & Direct unit cost & Partial direct unit cost \\
\hline \multirow[t]{2}{*}{ Arugula } & \multirow[t]{2}{*}{$41,212.12$} & Bed planting & $13,636.36$ & 0.33 & \multirow[t]{2}{*}{0.66} \\
\hline & & Crop harvest & $13,727.27$ & 0.33 & \\
\hline \multirow[t]{3}{*}{ Lettuce } & \multirow[t]{3}{*}{$36,363.64$} & Bed planting & $13,454.55$ & 0.37 & \multirow[t]{3}{*}{0.62} \\
\hline & & Bed maintenance & 4363.64 & 0.12 & \\
\hline & & Crop harvest & 4818.18 & 0.13 & \\
\hline \multirow[t]{4}{*}{ Broccoli } & \multirow[t]{4}{*}{$23,333.33$} & Bed fertilizing & 2272.73 & 0.10 & \multirow[t]{4}{*}{0.92} \\
\hline & & Bed planting & 8090.91 & 0.35 & \\
\hline & & Bed maintenance & 6545.45 & 0.28 & \\
\hline & & Crop harvest & 4636.36 & 0.20 & \\
\hline \multirow[t]{4}{*}{ Maize } & \multirow[t]{4}{*}{4545.45} & Bed fertilizing & 2272.73 & 0.50 & \multirow[t]{4}{*}{1.12} \\
\hline & & Bed planting & 909.09 & 0.20 & \\
\hline & & Bed maintenance & 1272.73 & 0.28 & \\
\hline & & Crop harvest & 636.36 & 0.14 & \\
\hline \multirow[t]{3}{*}{ Yam } & \multirow[t]{3}{*}{$18,181.82$} & Bed planting & 1181.82 & 0.07 & \multirow[t]{3}{*}{0.36} \\
\hline & & Bed maintenance & 4000.00 & 0.22 & \\
\hline & & Crop harvest & 1363.64 & 0.08 & \\
\hline \multirow[t]{4}{*}{ Cherry tomato } & \multirow[t]{4}{*}{$18,181.82$} & Bed fertilizing & 2272.73 & 0.13 & \multirow[t]{4}{*}{1.82} \\
\hline & & Bed planting & 1181.82 & 0.07 & \\
\hline & & Bed maintenance & $19,818.18$ & 1.09 & \\
\hline & & Crop harvest & 9818.18 & 0.54 & \\
\hline \multirow[t]{4}{*}{ Strawberry } & \multirow[t]{4}{*}{$36,363.64$} & Bed fertilizing & 1545.45 & 0.04 & \multirow[t]{4}{*}{0.72} \\
\hline & & Bed planting & 4545.45 & 0.13 & \\
\hline & & Bed maintenance & 4909.09 & 0.14 & \\
\hline & & Crop harvest & $15,272.73$ & 0.42 & \\
\hline \multirow[t]{3}{*}{ Okra } & \multirow[t]{3}{*}{1818.18} & Bed planting & 909.09 & 0.50 & \multirow[t]{3}{*}{3.60} \\
\hline & & Bed maintenance & 2454.55 & 1.35 & \\
\hline & & Crop harvest & 3181.82 & 1.75 & \\
\hline \multirow[t]{3}{*}{ Coffee } & \multirow[t]{3}{*}{751.52} & Bed planting & 90.91 & 0.12 & \multirow[t]{3}{*}{11.37} \\
\hline & & Bed maintenance & 1636.36 & 2.18 & \\
\hline & & Crop harvest & 6818.18 & 9.07 & \\
\hline
\end{tabular}

$1 \mathrm{US} \$=\mathrm{R} \$ 3.20$ in June, 2017

2009). This explains the low indirect unit costs of maintenance, fertilization and inputs.

It was then possible to determine the total indirect costs per product unit of the system (Table 10). As with direct costs, coffee has shown higher unit indirect cost due to the smaller amount produced and, therefore, the costs are passed on in greater proportion to the unit produced of this product. Coffee is the agroforestry product with the highest costs of production, while the yam is the product of lower cost of production. However, the system is still in development and therefore these products are in different stages of development (where coffee is still in development and the vegetables are in the production phase). Therefore, costs behave differently for each product, where coffee behaves as an investment opportunity for future crops, while vegetables as costgenerators.

Therefore, the ABC methodology when applied to crop integration systems should be analyzed considering the design of the system and the management carried out in the area, together with the accounting 
Table 6 Total direct costs $(\mathrm{R} \$ / \mathrm{ha})$ for each product of the analyzed agroforestry system

\begin{tabular}{lc}
\hline Product & Total direct unit cost \\
\hline Arugula & 0.93 \\
Lettuce & 0.79 \\
Broccoli & 1.21 \\
Maize & 1.90 \\
Yam & 0.46 \\
Cherry tomato & 2.15 \\
Strawberry & 1.09 \\
Okra & 3.83 \\
Coffee & 12.98 \\
\hline
\end{tabular}

$1 \mathrm{US} \$=\mathrm{R} \$ 3.20$ in June, 2017 results. By means of the information obtained, it was possible to determine the marginal contribution (Table 11), which represents the unit variable profit, that is, how much the producer will profit from each unit sold (Padoveze 2010).

Maize and okra had negative marginal contribution, showing that the respective production costs exceed the sales value of the product. And thus the products are not so attractive financially. The maize and okra marginal contribution results are related to the crop failure during the period analyzed for the study, which is responsible for influencing the costs demanded for production, impacting the financial attractiveness of the products.

It is important to register that the maize negative marginal contribution may be related to problems that
Table 7 Cost drivers used to apply the methodology
$1 \mathrm{US} \$=\mathrm{R} \$ 3.20$ in June, 2017

\begin{tabular}{lrl}
\hline Activity & Cost driver $(\mathrm{R} \$ / \mathrm{ha})$ & Cost driver unit \\
\hline Rotary brush cutter use & $13,636.36$ & Hour/machine \\
Bed fertilizing & 2931.82 & Man/day \\
Mulching (application) & 5772.73 & Man/day \\
Bed maintenance & $25,636.36$ & Man/day \\
Maintenance of the agroforestry bed & 9547.35 & Man/day \\
Cattle manure & $47,652.35$ & $\mathrm{~kg}$ \\
Mulching & 5629.55 & $\mathrm{~kg}$ \\
Irrigation (depreciation) & 6000.00 & Unit \\
Electric energy & $12,000.00$ & Unit \\
Total & $81,154.17$ & \\
\hline
\end{tabular}

Table 8 Indirect costs $(\mathrm{R} \$ / \mathrm{ha})$ of the activity per unit of product of the agroforestry system

\begin{tabular}{llllll}
\hline System activities & & & & \\
\hline Products & Rotary brush cutter & $\begin{array}{l}\text { Bed } \\
\text { use }\end{array}$ & $\begin{array}{l}\text { Mulching } \\
\text { fertilizing }\end{array}$ & $\begin{array}{l}\text { Bed } \\
\text { maintenance }\end{array}$ & $\begin{array}{l}\text { Maintenance of the agroforestry } \\
\text { bed }\end{array}$ \\
\hline Arugula & 1.33 & 0.005 & 0.005 & 0.005 & 0.007 \\
Lettuce & 1.12 & 0.007 & 0.007 & 0.007 & 0.011 \\
Broccoli & 1.85 & 0.010 & 0.010 & 0.010 & 0.016 \\
Maize & 2.24 & 0.223 & 0.223 & 0.223 & 0.350 \\
Yam & 0.72 & 0.043 & 0.043 & 0.043 & 0.068 \\
Cherry & 3.64 & 0.009 & 0.009 & 0.009 & 0.013 \\
tomato & 1.45 & 0.005 & 0.005 & 0.005 & 0.008 \\
Strawberry & 7.20 & 0.434 & 0.434 & 0.434 & 0.680 \\
Okra & 16.69 & 1.096 & 1.096 & 1.096 & 1.718 \\
Coffee & 36.23 & 1.83 & 1.83 & 1.83 & 2.87 \\
Total & & & & & \\
\hline
\end{tabular}

$1 \mathrm{US} \$=\mathrm{R} \$ 3.20$ in June, 2017 
Table 9 Indirect costs $(\mathrm{R} \$ /$ ha) of inputs related to activities per unit of output

\begin{tabular}{lllll}
\hline Inputs related to activities & & & \\
\hline Products & Cattle manure & Mulching & Irrigation (depreciation) & Electric energy \\
\hline Arugula & 0.000020 & 0.000005 & 0.003023 & 0.001 \\
Lettuce & 0.000030 & 0.000008 & 0.004604 & 0.001 \\
Broccoli & 0.000044 & 0.000012 & 0.006781 & 0.001 \\
Maize & 0.000957 & 0.000260 & 0.147321 & 0.025 \\
Yam & 0.000186 & 0.000051 & 0.028646 & 0.005 \\
Cherry tomato & 0.000037 & 0.000010 & 0.005666 & 0.001 \\
Strawberry & 0.000023 & 0.000006 & 0.003568 & 0.001 \\
Okra & 0.001860 & 0.000506 & 0.286458 & 0.048 \\
Coffee & 0.004696 & 0.001278 & 0.723177 & 0.121 \\
Total & 0.0079 & 0.0021 & 1.2092 & 0.2015 \\
\hline
\end{tabular}

Table 10 Total indirect costs ( $\mathrm{R} \$ / \mathrm{ha}$ ) per product of the agroforestry system

\begin{tabular}{lc}
\hline Products & Product total indirect unit cost \\
\hline Arugula & 1.35 \\
Lettuce & 1.16 \\
Broccoli & 1.90 \\
Maize & 3.43 \\
Yam & 0.95 \\
Cherry tomato & 3.69 \\
Strawberry & 1.47 \\
Okra & 9.52 \\
Coffee & 22.55 \\
\hline
\end{tabular}

$1 \mathrm{US} \$=\mathrm{R} \$ 3.20$ in June, 2017

the producer had during the seeds selection in relation to the management objectives. This situation may had influence the seed quality, that had problems during the germination (the seeds used in the analyzed system were from 2007). Therefore, it can be concluded that these were a circumstantial problem, and not problem of culture in agroforestry systems with this design profile. In the case of okra, the agricultural spacing utilized was lower than the standard in monoculture, but its densification may cause excessive shading to other vegetables, which demonstrates its non-viability. But Mattos (2015) remembers that it is necessary to be careful in these interpretations, since the farmers declare that there are fundamental products to attract consumers in the street markets, like lettuce, tomato and carrot (basic Brazilian salad). Even though some products represent financial losses, they are strategic to attract the consumption of others profitable products. But it is not the case with okra in this case study.

The other products have positive marginal contributions, highlighting yam and strawberry. In this analysis, the strawberries may represent a positive scenario for the producer and an investment possibility, since this product has the highest marginal
Table 11 Unit costs of production $(\mathrm{R} \$ / \mathrm{ha})$, sale price $(\mathrm{R} \$)$ and product marginal contribution (\%)

$1 \mathrm{US} \$=\mathrm{R} \$ 3.20$ in June, 2017

\begin{tabular}{lccccc}
\hline Products & Direct costs & Indirect costs & Total costs & Sale price & Contribution margin \\
\hline Arugula & 0.93 & 1.35 & 2.28 & 10.00 & 77.19 \\
Lettuce & 0.79 & 1.16 & 1.95 & 9.00 & 78.35 \\
Broccoli & 1.21 & 1.90 & 3.11 & 10.00 & 68.90 \\
Maize & 1.90 & 3.43 & 5.33 & 4.50 & -18.48 \\
Yam & 0.46 & 0.95 & 1.41 & 8.00 & 82.35 \\
Cherry tomato & 2.15 & 3.69 & 5.84 & 13.50 & 56.77 \\
Strawberry & 1.09 & 1.47 & 2.57 & 18.00 & 85.73 \\
Okra & 3.83 & 9.52 & 13.35 & 11.00 & -21.39 \\
Coffee & 12.98 & 22.55 & 35.53 & 60.00 & 40.78
\end{tabular}


contribution and the highest selling price, representing a potential higher financial return to the producer.

Despite the lower selling price of the yam, this product also represents a positive potential for the producer, since its production costs, both direct and indirect, are low and, therefore, represents low demand by resource for its production. In addition, strawberries and yams are products with a long harvest period, thus ensuring that the producer's financial returns occur over a longer period. The strawberry had problems of losses of harvests in some years, but nevertheless it is excellent alternative of financial gains. And the recent results of national research on the nutritional benefits of yams have raised the consumption of the product by Brazilians.

\section{Conclusions}

Once the agroforestry system has been financed, it is concluded that the products are profitable to the producer, with the exception of occasional results of maize and okra in this case study. But the total profitability of the agroforestry system covers the losses proportionated by this occasional maize result. Therefore, determining the unit costs of production and knowing the contribution margin of the products of a production system, together with a market analysis, allows the production of certain products to be prioritized in the next harvest and, consequently, the producer has the possibility of greater financial returns.

The application of the $\mathrm{ABC}$ costing methodology is efficient for the management and administration of agroforestry projects, allowing the producer to know the flow of resources invested in production. It makes it possible to identify the way in which the mix of products in the system relate to their respective production costs. In this way, it is possible that new production strategies will be traced to the next harvests, in order to optimize the production of the system.

\section{References}

Altieri MA, Nicholls CI (2011) O potencial agroecológico dos sistemas agroflorestais na América Latina. Agriculturas: Experiências em Agroecologia, Rio de Janeiro 8(2):31-34
Anzai Y, Heilbrun ME, Haas D, Boi L, Moshre K, Minoshima S, Kaplan R, Lee VS (2017) Dessecting costs of CT Study: application of TDABC (time driven activity-based costing) in a tertiary academic center. Acad Radiol 24(2):200-208

Association for Temperate Agroforestry-AFTA. What is agroforestry. http://aftaweb.org/about/what-isagroforestry.html. Accessed 24 Oct 2016

Bentes-Gama MM (2003) Análise técnica e econômica de sistemas agroflorestais na Amazônia Ocidental, Machadinho D’Oeste, Thesis, Universidade Federal de Viçosa

Bentes-Gama MM, Silva ML, Vilcahuamán LJM, Locatelli M (2005) Análise econômica de sistemas agroflorestais na Amazônia Ocidental, Machadinho D'Oeste-RO. Revista Árvore 29(3):401-411

Carli G, Canavari M (2013) Introducing direct costing and activity based costing in a farm management system: a conceptual model. 6th international conference on information and communicationtechnologies in agriculture, Food and Environment, Procedia Techonology 8:397-405

Cremonese DT, Tomi GDE, Neves MR (2016) Cost modelling of the product mix from mining operations using the activity-based costing approach. Revista Escola de Minas 69(1):97-103

Diehl CA, Souza MA, Alves TW (2008) Custeio baseado em atividades (ABC): Um estudo sobre publicações em eventos científicos. XXXII Encontro da ANPA, Rio de Janeiro

Garrison RH, Noreen EW, Brewer PC (2013) Contabilidade Gerencial, 14th edn. AMGH, Porto Alegre

Martins E (2010) Contabilidade de Custos. 10.ed. São Paulo: Atlas

Mattos L (2015) Caracterização agronômica dos sistemas de produção e análise dos processos de tomada de decisão sobre uso da terra nos estabelecimentos rurais que compõem a Associação de Agricultura Ecológica (age)/Distrito Federal (DF). 53 Congressso da SOBER-Sociedade Brasileira de Economia, Administração e Sociologia Rural, João Pessoa

Moraes MD, Oliveira LC, Tarsitano MAA, Sant'ana AL, Gonzaga DA (2013) Estimativa do custo de implantação do Sistema Agroflorestal "Café com Floresta" no Assentamento Estrela da Ilha, Ilha Solteira-SP. Cadernos de Agroecologia 8(2):1-5

Padoveze C (2010) Contabilidade gerencial: um enfoque em sistema de informação contábil. 7.ed. Atlas

Padoveze LC, Takakura Junior KF (2013) Custo e preços de serviços: logística, hospitais, transporte, hotelaria, mão de obra, serviços em geral. Atlas, São Paulo

Pimenta ML, Rocha MP, Lemes S (2007) Aplicação do método ABC no cultivo de hotaliças na região do Alto Paranaíba. Custos e @ gronegócio 3(2):2-21

Rezende BLA, Barros Junior AP, Cecílio Filho AB, Pôrto DRQ, Martins MIEG (2009) Custo de produção e rentabilidade das culturas de alface, rabanete, rúcula e repolho em cultivo solteiro e consorciadas com pimentão. Ciência e Agrotecnologia, Lavras 33(1):305-312

Roschel LF, Borgert A, Souza FR (2013) Estruturação de um modelo de custeio baseado em atividades numa empresa prestadora de serviços. Revista de Estudos Contábeis 4(7):20-38 
Sampaio CH, Simões C, Perin MG, Almeida A (2011) Marketing metrics: Insights from Brazilian managers. Ind Market Manage 40:8-16

Silvestre WC (2002) Sistema de Custos ABC - Uma visão avançada para tecnologia de informação e avaliação de desempenho. 1 ed. Atlas

Souza HN, Graff J, Pullerman MM (2012) Strategies and economics of farming systems with coffee in the Atlantic Rainforest Biome. Agrofor Syst 84:227-242

Suthummanon S, Ratanamanee W, Boonyanuwat N, Saritprit P (2011) Applying activity-based costing (ABC) to a parawood furniture factory. Eng Econ 56:80-93
Wernke R (2005) Custeio baseado em atividades (ABC) aplicado aos processos de compra e venda de distribuidora de mercadoria. Revista de Contabilidade Finanças 38:74-89

World Agroforestry Centre-ICRAF (2011) Políticas públicas para o desenvolvimento agroflorestal no Brasil. BelémPará, p 80

Publisher's Note Springer Nature remains neutral with regard to jurisdictional claims in published maps and institutional affiliations. 